\title{
How easy is it Possible to increase or Decrease the Amount of Milk in Lactating Mothers?
}

\author{
Jalil Rashedi ${ }^{1}$, Behroz Mahdavi Poor ${ }^{1,2 *}$ and Mohammad Asgharzadeh ${ }^{2}$ \\ ${ }^{1}$ Department of Laboratory Science, Tabriz University of Medical Sciences, Iran \\ ${ }^{2}$ Department of Medical Parasitol $\neg$ gy, Tarbiat Modarres University, Iran \\ ${ }^{3}$ Biotechnology Research Center and Faculty of Paramedicine, Tabriz University of Medical Sciences, Iran
}

Submission: February 21, 2018 ; Published: March 15, 2018

"Corresponding author: Behroz Mahdavi poor, Department of Laboratory Science, Faculty of Paramedicine, Tabriz University of Medical Sciences \& Department of Medical Parasitol $\neg$ ggy, School of Medical Sciences, Tarbiat Modarres University, Tehran, Iran, Tel: +9841-33392633; Fax: +984133371971; Email: Behroz.mahdavi@gmail.com

\section{Letter to Editor}

In the last centuries, Iranian physicians such as Abu Bakr Mohammad Ibn Zakariya Razi ( $9^{\text {th }}-10^{\text {th }}$ century AD) in book of "Man La Yahzoroh al-Tabib" [1], Avicenna $\left(10^{\text {th }}-11^{\text {th }}\right.$ century AD) in "Al-Qanun fi al-Tibb, third book" [2] and Seyyed Mohammd Hossein Aghili Khorasani-e Shirazi $\left(17^{\text {th }}-18^{\text {th }}\right.$ century AD) in "Makhzan ol-Advieh" [3], wrote approximately similar instructions to increase (Table 1) or decrease the amount of milk in lactating mothers. The most important ones are as following: Table 1: Instruction to increase the amount of milk in mothers who have low milk.

\begin{tabular}{|c|c|}
\hline Herbal Elements & Weight \\
\hline Anethum graveolens dhi seeds & $35 \mathrm{gr}$ \\
\hline Allium ampeloprasum seeds & $35 \mathrm{gr}$ \\
\hline Trifolium seeds & $35 \mathrm{gr}$ \\
\hline Trigonella foenum-graecum seeds & $35 \mathrm{gr}$ \\
\hline Medicago sativa L. (Alfalfa seeds ) & $35 \mathrm{gr}$ \\
\hline
\end{tabular}

Grind all ingredients and mix with distillation of Foeniculum vulgare \& some honey and take every day.

Note: Foeniculum vulgare is the most well-known material in this field focused in other ancient medical texts such as Tohfat al-Mumen in by Mohammad Mumen Mir Mohammad Zaman Tonekaboni (17th-18th century AD).

In a mother who feeds her baby and the amount of milk in the breast exceeds the normal. The over-production of the milk may lead to some complications in the breast. Even in some cases, milk flow spontaneously from the breast, unassociated with childbirth or nursing, Galactorrhea [4]. To solve the problem, materials such as Lactuca sativa seeds, Vitex agnus-castus seeds, Caraway (Carum carvi) and Lens culinaris can be helpful. Another way is to mix Caraway (Carum carvi) with vinegar and rub on the breast.

Note: Caraway (Carum carvi) is a material (as topical) which has been mentioned in other Iranian ancient medical sources such as Tohfat al-Mumenin ( $17^{\text {th }}$ century AD) [5] in this regard.

Considering the nature of these materials may open a new window for researchers in this field.

\section{References}

1. Rhazes Man La, Yahzoroh al-Tabib (1983) Trans into Persian by Nafisi A. Jahad daneshghahi Publications, Tehran, Iran.

2. Avicenna, Al-Qanun fi al-Tibb (2010) Trans Into Persian by Sharafkandi A. Soroush publications, Tehran, Iran, pp. 565-570.

3. Aghili Shirazi MH, Makhzan-ol-Advieh (2009) Store house of Medicaments. Rah-e Kamal Publications, Tehran, Iran, p. 406.

4. Huang W, Molitch ME (2012) Evaluation and management of galactorrhea. Am Fam Physician 85(11): 1073-1080.

5. Tonekaboni MM, Tohfat al-Mumenin (2007) Corrected by Roja R, Shams-e Ardakani M R, Farjadmand F. Nashre shahr publications, Tehran, Iran, p. 370. 
This work is licensed under Creative Commons Attribution 4.0 License

DOI: 10.19080/JGWH.2018.09.555753
Your next submission with Juniper Publishers

will reach you the below assets

- Quality Editorial service

- Swift Peer Review

- Reprints availability

- E-prints Service

- Manuscript Podcast for convenient understanding

- Global attainment for your research

- Manuscript accessibility in different formats

( Pdf, E-pub, Full Text, Audio)

- Unceasing customer service

Track the below URL for one-step submission https://juniperpublishers.com/online-submission.php 